ISSN 1996-1944

www.mdpi.com/journal/materials

Review

\title{
Toxicity of Transition Metal Oxide Nanoparticles: Recent Insights from in vitro Studies
}

\author{
Yue-Wern Huang *, Chi-heng Wu and Robert S. Aronstam \\ Department of Biological Sciences and the Missouri S\&T cDNA Resource Center, Missouri \\ University of Science and Technology, 400 W. 11th Street, 105 Schrenk Hall, Rolla, MO 65409, USA; \\ E-Mails: cwc33@mst.edu (C.-H.W.); aronstam@mst.edu (R.S.A.) \\ * Author to whom correspondence should be addressed; E-Mail: huangy@ mst.edu; \\ Tel.: +1-573-341-6589; Fax: +1-573-341-4821.
}

Received: 5 October 2010 / Accepted: 22 October 2010 / Published: 25 October 2010

\begin{abstract}
Nanotechnology has evolved to play a prominent role in our economy. Increased use of nanomaterials poses potential human health risk. It is therefore critical to understand the nature and origin of the toxicity imposed by nanomaterials (nanotoxicity). In this article we review the toxicity of the transition metal oxides in the 4th period that are widely used in industry and biotechnology. Nanoparticle toxicity is compellingly related to oxidative stress and alteration of calcium homeostasis, gene expression, pro-inflammatory responses, and cellular signaling events. The precise physicochemical properties that dictate the toxicity of nanoparticles have yet to be defined, but may include element-specific surface catalytic activity (e.g., metallic, semiconducting properties), nanoparticle uptake, or nanoparticle dissolution. These in vitro studies substantially advance our understanding in mechanisms of toxicity, which may lead to safer design of nanomaterials.
\end{abstract}

Keywords: nanoparticle; toxicity; metal oxide; oxidative stress; calcium homeostasis; signal transduction

\section{Overview}

Nanotechnology involves the study of the control of matter on atomic and molecular scales. Nanomaterials have at least one dimension in the range of 1-100 $\mathrm{nm}$ [1]. Nanotechnology is being applied in diverse fields, including extensions of conventional device physics, new approaches based 
upon molecular self-assembly, the development of novel materials with dimensions on the nanoscale, and even the direct control of matter on the atomic scale. The application of nanotechnology in biology (nanobiotechnology) encompasses development of nanomaterials for delivering and monitoring biologically active molecules, disease staging, therapeutical planning, surgical guidance, neuro-electronic interfaces, and electronic biosensors.

In 2000 the U.S. National Science Foundation estimated that the market for nanotechnology products will be over one trillion US dollars by 2015. This increase in use will likely lead to unintended exposures to nanomaterials by occupational workers and end product users via inhalation, dermal absorption, or gastrointestinal tract absorption. In particular, the direct use of nanomaterials in humans for medical and cosmetic purposes dictates vigorous safety assessment of toxicity. Presently, the adverse effects of such exposure on human health and the environment are incompletely understood [2].

Nanotoxicology is an emerging field that builds upon previous work on airborne particle toxicity. Given (1) fixed particle mass, (2) unitary density, and (3) particle surface bioreactivity, nanoparticles possess better tissue penetration and higher biological potency than coarse $(2.5-10 \mu \mathrm{m})$ and fine $(<2.5 \mu \mathrm{m})$ particles, reflecting their small sizes and large reactive surfaces (Figure 1). Inhaled particles and fibers generate oxidants including reactive oxygen species (ROS) and reactive nitrogen species (RNS) [3-5]. Knaapen et al. characterized the generation of cellular ROS/RNS as "primary source" if arising from the target cells themselves or "secondary source" if arising from inflammatory cells [6]. Oxidative stress (OS) plays important roles in cellular signaling, inflammatory, and genotoxic and proliferative responses [5-11]. A three-tiered response to oxidative stress model has been outlined [12]: The first tier involves the induction of antioxidant enzymes such as HO-1, NQO1, superoxide dismutase, catalases and glutathione peroxidases. If tier 1 protection fails to restore cellular redox equilibrium, tier 2 responses involving activation of pro-inflammatory signaling pathways such as the JNK and NF- $\mathrm{kB}$ cascades are triggered. At higher and more prolonged oxidative stress levels, cellular perturbation and disarray result in a decrease in mitochondrial membrane potential, leading to cell death.

Figure 1. Assuming an equal particle mass, as particle sizes decrease, surface areas increase. (Yue-wern Huang and Hannah Huang, unpublished data).

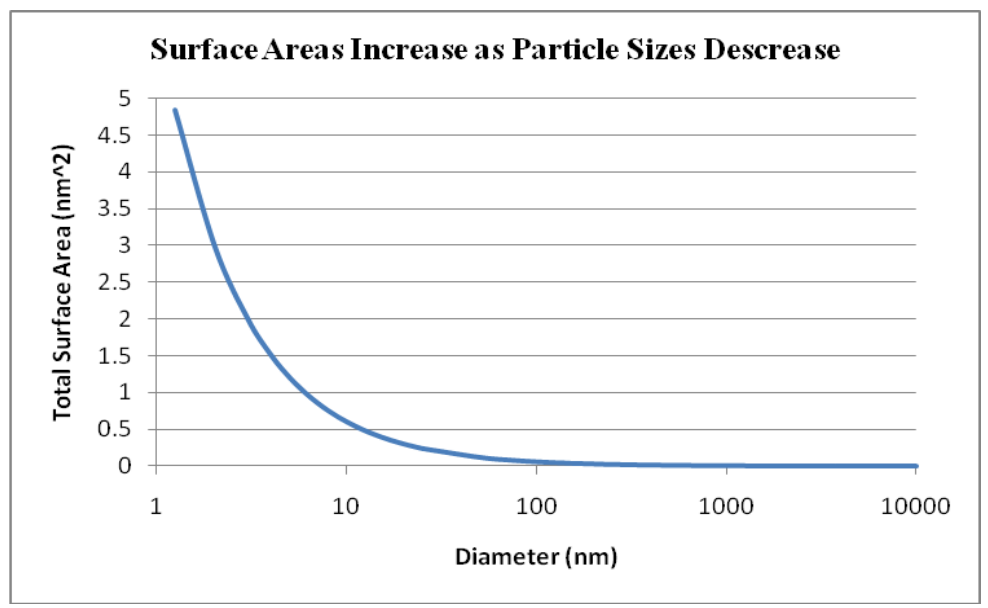




\section{Transition Metal Oxide Nanoparticles and their Applications}

Transition metal oxides are used in catalysis [13], magnetocooling [14], optical and recording devices [15-16], purification of enzymes and other biological materials [17], water purification devices [18], magnetic field assisted radionuclide therapy [19], embolics [20-22], and targeted drug delivery [23]. Among the transition metal oxides, titanium dioxide $\left(\mathrm{TiO}_{2}\right)$, cupric oxide $(\mathrm{CuO})$, and zinc oxide $(\mathrm{ZnO})$ have received the most attention due to their unique physical and chemical properties.

$\mathrm{TiO}_{2}$ allows osseointegration of artificial medical implants and bone. $\mathrm{TiO}_{2}$ is also extensively used as a pigment, a thickener, and a UV absorber in cosmetic and skin care products. $\mathrm{TiO}_{2}$, particularly in the anatase form, is a photocatalyst under ultraviolet light. It can be employed for solar energy conversion: Dye, polymer, or quantum dot sensitized nanocrystalline $\mathrm{TiO}_{2}$ solar cells can be manufactured using conjugated polymers as solid electrolytes. $\mathrm{TiO}_{2}$ is also used as a material in the memristor, a new electronic circuit element.

Nanostructures of $\mathrm{ZnO}$, including particles, rods, wires, belts, tubes, cages, walls, and rings, have found utility due to their unique nanoscaled electronic and optoelectronic properties [24-30]. $\mathrm{ZnO}$ has wide direct band gap ( $3.37 \mathrm{eV}$ or $375 \mathrm{~nm}$ at room temperature), making it suitable for use in laser diodes and light emitting diodes. $\mathrm{ZnO}$ has high biocompatibility and fast electron transfer kinetics; these features enable the use of this material as a biomimic membrane to immobilize and modify biomolecules [31]. Other applications are in catalysis, paints, abrasives, wave filters, UV detectors, transparent conductive films, varistors, gas sensing, solar cells, sunscreens, and cosmetic products.

Cupric oxide $(\mathrm{CuO})$ is used as a pigment in ceramics to produce blue, red, and green (and sometimes gray, pink, or black) glazes. $\mathrm{CuO}$ is a p-type semiconductor due to its narrow band gap of $1.2 \mathrm{eV}$. $\mathrm{CuO}$ can be used to produce dry cell batteries as well as wet cell batteries as the cathode. $\mathrm{CuO}$ is used as an abrasive to polish optical equipment, and it can be used to dispose of hazardous materials such as cyanide, hydrocarbons, halogenated hydrocarbons and dioxins via oxidation processes.

\section{Methodologies to Study Toxicity of Transition Metal Oxides}

Both in vitro and in vivo methods provide valuable tools to investigate nanotoxicity. In this article, we review in vitro studies. In vitro toxicity testing is a cost effective tool to evaluate the toxicity of nanomaterials; there are too many nanomaterials to evaluate each in vivo. Some advantages of in vitro studies using various cell lines are that they: (1) reveal effects of target cells in the absence of secondary effects caused by inflammation; (2) permit the identification of primary mechanisms of toxicity in the absence of the physiological and compensatory factors that confound the interpretation of whole animal studies; and (3) are efficient, rapid and cost-effective; and 4) can be used to improve design of subsequent expensive whole animal studies. For instance, we and others have used A549 (human bronchoalveolar carcinoma-derived cells), U87 (astrocytoma cells), U937 (human monoblastoid cells), mouse Leydig TM3 cells, human V79 and L929 fibroblasts, human SCCVII, B16F10 and FsaR tumor cells, and RAW264.7 (mouse peritoneal macrophage) cell lines to characterize oxidative stress-related signaling pathways [32-42]. A nontransformed human lung cell line (BEAS-2B) has been used to decipher expression of alteration of genes pertaining to oxidative 
stress and cell death pathways [43-44]. Co-culture of cell lines is another valuable technique to manipulate environmental influences in vitro studies [45].

A limitation of in vitro testing is that cells in culture do not experience the range of pathogenic effects observed in vivo, partly related to issues of translocation, toxicokinetics and coordinated tissue responses. A detail discussion of the limitations of in vitro studies can be found in Donaldson et al. [46].

\section{Mechanisms of Cellular Uptake and Intracellular Interactions}

Transmission electron microscopy (TEM) and scanning electron microscopy (SEM) have been the most widely used techniques to visualize agglomerated nanoparticles in cells [35,40-41,47]. To understand mechanisms of cellular uptake of nanoparticles, we recommend live cell imaging techniques, as cell fixation process can alter membrane properties leading to artificial uptake of nanoparticles [48]. Fluorescent probes such as Texas Red and FITC can be conjugated to nanoparticles to ascertain bioavailability. Studies on uptake mechanisms of transition metal oxide nanoparticles are limited; however, the following findings on the uptake of quantum dots, carbon nanotubes, gold nanoparticles, and silicon nanoparticles are likely to be relevant to transition metal oxides.

Cationic nanoparticles may enter cells more easily than anionic nanoparticles since cationic nanoparticles can interact with heparin sulfate proteoglycans on the membrane surface [49-50]. This increased bioavailability may explain why cationic silicon nanoparticles are more toxic than neutral and anionic silicon nanoparticles [51]. This electrostatic interaction is a prelude for a subsequent endocytic process. Exogenous materials can be internalized via multiple pathways, including clathrin-mediated endocytosis, caveolar-mediated endocytosis, macropinocytosis, phagocytosis, flotillin-dependent endocytosis, arf6-dependent endocytosis, IL2R $\beta$ endocytic pathway, CLIC/GEEC endocytic pathway, circular doral ruffles, and trans-endocytosis. A few studies have suggested that the uptake of nanomaterials involves energy-, lipid raft- and actin-dependent macropinocytosis. Phagocytosis is an alternate proposed venue of entry. For instance, single wall carbon nanotubes conjugated with proteins as cargoes enter cells via energy-dependent pathways and become entrapped inside endosome/lysosomes [52]. We have observed that $\mathrm{CdSe} / \mathrm{ZnS}$ quantum dots non-covalently conjugated with nona-arginines are internalized via lipid raft dependent macropinocytosis, and the complex is confined in lysosomes [53-54]. One study has demonstrated that Tat peptide-conjugated quantum dots (Tat-QD) are internalized via actin-dependent endocytosis, transported by microtubules, and aggregated around microtubule-organizing center; the Tat-QD vesicle are shed from filopodia [55]. On the other hand, gold nanoparticles conjugated with biomolecules are internalized via phagocytosis by mouse macrophages [56], and organic monolayer-coated silicon nanoparticles are phagocytosed by rat alveolar macrophage cells (NR8383) [51]. Clearly, studies on uptake mechanisms of transition metal oxides are needed.

\section{Toxicity of Transition Metal Oxide Particles}

Using commercially available raw nanoparticles to test toxicity is essential to understand human health risk and environmental impact, as this addresses unintended exposure. It is equally important to test surface modified-nanoparticles, as these modified nanoparticles have different kinetics and 
bioavailability than the native nanoparticles, and they are frequently applied directly on human body for purposes such as disease diagnostics, treatment, and prognostics.

The toxicological literature reveals a trend among these transition metal oxides: $\mathrm{TiO}_{2}$ is less toxic than $\mathrm{CuO}$ and $\mathrm{ZnO}$ in human cell lines [33,35,43,57-58]. A similar trend was observed in E. Coli [59] and yeast [60]. Using BEAS-2B cells, we investigated the toxicity of oxides of Cr, Mn, $\mathrm{Fe}, \mathrm{Co}, \mathrm{Ni}, \mathrm{Cu}$, and $\mathrm{Zn}$, each of which is widely used in industry and is in the same period as $\mathrm{Ti}\left(\mathrm{V}_{2} \mathrm{O}_{3}\right.$ particles were excluded from this analysis because they are not commercially available in the same size range and morphology as the other compounds). Toxicity increased with atomic number (Figure 2), with the exceptions of $\mathrm{Fe}_{2} \mathrm{O}_{3}$ (lower toxicity than expected) and $\mathrm{CoO}$ (higher toxicity than expected). Fahmy and Cormier also identified a similar relationship of $\mathrm{CuO}$ and $\mathrm{Fe}_{2} \mathrm{O}_{3}$ toxicity in airway epithelial cells (HEp-2) [39]. It is difficult to compare the toxicity of $\mathrm{TiO}_{2}$ and $\mathrm{V}_{2} \mathrm{O}_{5}$, as synthesis methods, particle characteristics, and cell lines (Leydig TM3 cells, human V79 and L929 fibroblasts, human SCCVII, B16F10 and FsaR tumor cells) differ among the few published studies; however, it is quite clear that $\mathrm{TiO}_{2}$ is minimally toxic while $\mathrm{V}_{2} \mathrm{O}_{5}$ is toxic [40-42]. Data from these studies are consistent with our findings presented in Figure 2.

Figure 2. Cytotoxicity of eight transition metal oxides in BEAS-2B cells exposed for $24 \mathrm{~h}$. (adapted from [43], with additional data).

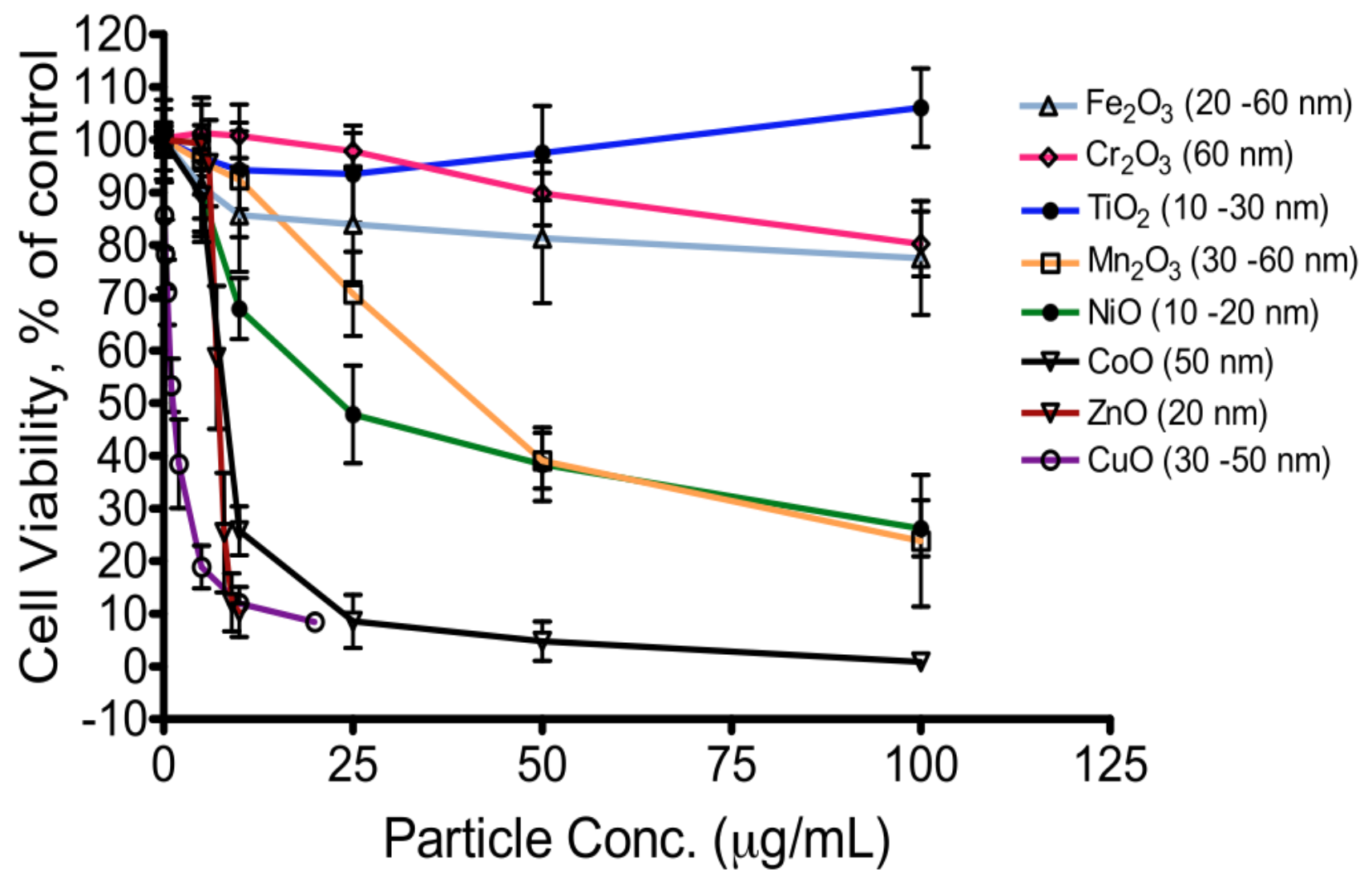

While the factors underlying this trend have not been established, several physicochemical properties have been considered, including element-specific catalytic activity on the particle surface, released ions (particle dissolution), and differential cellular uptake. In a study with A549 cells, Limbach et al. [61] demonstrated that 1) among titanium-, manganese-, iron-, or cobalt-doped silica, 
the addition of $\mathrm{Ti}$ or Fe has a much smaller effect on ROS generation than Mn due in part to surface catalytic activity; and 2) particles of $\mathrm{Co}_{3} \mathrm{O}_{4}$ and $\mathrm{Mn}_{3} \mathrm{O}_{4}$, but not $\mathrm{TiO}_{2}$ and $\mathrm{Fe}_{2} \mathrm{O}_{3}$, can significantly dissolve in a cell-free culture system leading to elevated ROS levels. They further demonstrated that much less ROS is formed when an aqueous iron solution contains A549 cells than when the solution contains no cells. The authors attributed this difference to a barrier function of the cell membrane for ions. It is also likely that that adsorption and binding of the metal oxide particles to the matrix of the cell medium may also be involved [62].

The potential role of dissolved ions in toxicity was also highlighted in a study by George et al. [63]. They found remarkably high levels of $\mathrm{Zn}^{2+}$ released into aqueous solutions from pure and Fe-doped $\mathrm{ZnO}$ nanoparticles. In one study, we suspended transition metal oxides in an aqueous solution for a period of 6 hours, and utilized a dialysis membrane with a molecular weight cutoff 500-1,000 to separate ionic species. We observed a trend of increased ion dissolution of metal oxides from $\mathrm{TiO}_{2}$ (0.0017\%-0.0065\%, wt based) to $\mathrm{ZnO}(1.25 \%-1.67 \%$, wt based) (Huang et al. unpublished data), corresponding to the toxicity trend (Figure 2). While initial attempts to measure ion dissolution from metal oxide nanoparticles have been made by us and others, it would be desirable to assess ion dissolution in a cell medium relevant setting using a standardized protocol to separate dissolved ions. Moreover, $\mathrm{pH}$ maintenance during the experimental protocol is essential to allow comparisons with the cellular environment, and adsorption effects by culture medium can complicate the subsequent ICP-MS analysis and must be taken into consideration.

While Limbach's findings [61] may explain the relatively low toxicity of $\mathrm{Fe}_{2} \mathrm{O}_{3}$, it is not obvious why $\mathrm{CoO}$ is more toxic than $\mathrm{NiO}$. We suspect involvement of a variety of factors: surface catalytic activity, released ion, cell membrane as a barrier, adsorption to the matrix of the cell medium, cellular uptake, and possibly point of zero charge. Experiments using oxides of different oxidation states (CoO, $\mathrm{Co}_{3} \mathrm{O}_{4}, \mathrm{NiO}, \mathrm{Ni}_{2} \mathrm{O}_{3}$ ) may be revealing in this regard.

Although we and others have contributed to the understanding of the physico-chemical properties governing cytotoxicity of transition metal oxides, there are still gaps in our knowledge. While studies on nanoparticles of industrial origin have contributed to risk assessment and management, these materials possess considerable heterogeneity in size, morphology, surface defects, etc. This makes it difficult to relate toxicity to specific particle characteristics. Thus, it is desirable to synthesize highly defined and uniform nanoparticles to identify the toxicity-contributing properties of nanoparticles for comparative and predictive nanotoxicology. Not only would this type of particles enrich our knowledge of particle physics, chemistry and biology, it would also assist in the design and production of safer alternative particles.

\section{Mechanisms of Action of Toxicity}

\subsection{Exposure to Metal Oxides Tips Off Cellular Redox State-Elevated Oxidative Stress}

Oxidative stress is a normal cellular process involved in many aspects of cellular signaling, though excessive oxidative stress can be harmful. Many studies have shown that exposure to nanoparticles elevates cellular oxidative stress [34-35,37-39,61]. To cope with elevated oxidative stress, cells mount protective or injurious responses. For instance, cells activate enzymatic and non-enzymatic antioxidant defense mechanisms. Glutathione peroxidases, catalases, superoxide dismutases, and phase II enzymes 
play essential roles in returning cells to a normal redox state (Figure 3). The transcription factor Nrf-2 has been shown to play an essential role in the antioxidant response element (ARE)-mediated expression of phase II detoxifying and antioxidant enzymes, as well as other stress-inducible genes, in response to oxidative stress [64-66]. A recent study with $\mathrm{CeO}_{2}$ nanoparticles has demonstrated that $\mathrm{Nrf}-2$ can be activated and translocated into nucleus with subsequent induction of heme oxygenase-1 (HO-1) in $\mathrm{CeO}_{2}$-exposed BEAS-2B cells [67]. Nrf-2 can therefore be considered as a master switch for antioxidation defense, serving as a functional indicator of oxidative insult caused by nanomaterials.

In our pathway-specific microarray study involving 84 oxidative stress responsive genes [20], exposure of BEAS-2B cells to a ROS-elevated but sublethal concentration of $\mathrm{ZnO}$ nanoparticles elevates the expression of genes pertaining to oxidative stress (PRDX3, PRNP, and TXNRD1 genes) and apoptosis (a pro-apoptotic BNIP3 gene). This is consistent with our biochemical and cytotoxicity findings. One caution in assessing gene regulation under oxidative stress is that the response is quite dynamic and dependent on somewhat arbitrary cutoff criteria relative to control levels. For instance, we did not find elevated expressions of several common antioxidant genes, including catalase, glutathione peroxidase, glutathione reductase, glutathione transferase, and superoxide dismutase in cells exposed to $\mathrm{ZnO}$ at the ROS-elevated but sublethal level [20]. This finding is consistent with results reported by Sarkar et al. [44] with toxic single-walled carbon nanotubes in BJ Foreskin cells. At different time points or concentrations (i.e., stress levels), gene expression may be alternately up-regulated or down-regulated.

Figure 3. An example of metabolism of nanoparticle-induced oxidative stress and resulting toxicity.

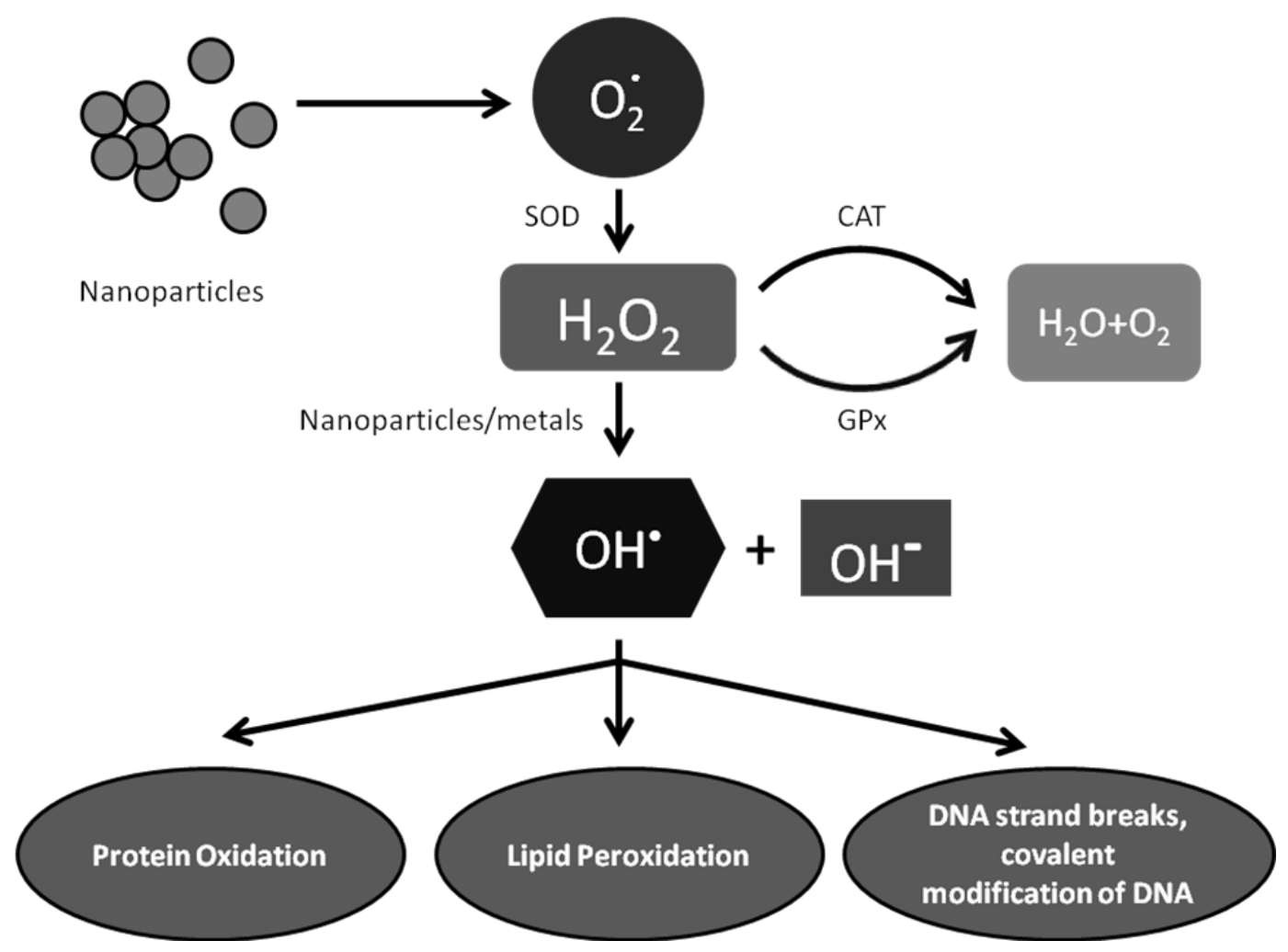

Understanding the regulation of enzymatic and non-enzymatic antioxidant defense mechanisms may suggest strategies to mitigate elevated oxidative stress. For example, Gilliland et al. used 
knockout and genetic polymorphisms of genes that encode phase II enzymes to characterize a susceptibility mechanism that may explain why only some people develop PM-induced injury [68]. Catalase and glutathione peroxidase are two other examples: Catalase has a relatively low constitutive level in cardiomyocytes which predisposes cardiac muscle to oxidative stress damage. Cardiac muscle is also very susceptible to oxidative damage due in part to the rapid inactivation of glutathione peroxidase [69]. Overexpression of glutathione peroxidase in endothelial cells and myocytes significantly decreases oxidative stress-induced NF-kB activation, which leads to apoptosis [70]. Thus, tissue-specific responses to nanoparticle exposure should be considered when risk assessment is performed.

The fundamental factor that governs initiation of cellular oxidative stress by transition metal oxides is still unknown. Oxygen vacancies on metal-oxide surfaces are electrically and chemically active. Once entering circulatory systems or cells, charge accepting molecules, such as $\mathrm{NO}_{2}$ and $\mathrm{O}_{2}$, may be in close proximity at the vacancy sites; de-coupling of charged $\mathrm{NO}_{2}$ or $\mathrm{O}_{2}$ is possible and could be sources of initiation of oxidative stress. Interestingly, non-metal nanomaterials such as carbon nanotubes behave like (transition) metal oxides in inducing cellular oxidative stress. We hypothesize that oxidative stress initiated by metal or non-metal nanoparticles may be related to their metallic or semiconducting properties at nano-scale sizes. It remains to be determined how the metallic or semiconducting behaviors and metal dissolution differentially contribute to initiation of cellular oxidative stress and subsequent pathologic outcome.

When oxidative stress overwhelms defense mechanisms, cellular macromolecules such as proteins, lipids, and DNA are subject to damage. DNA damages include deletions, mutations, single- and double-strand breakages, adduct formation, and cross-linking with proteins. Studies have confirmed DNA adducts and oxidation-induced DNA fragmentation following exposure to metal oxide nanoparticles $[35,58,71-73]$. In response to DNA insult, cells attempt to repair the damaged DNA. Repair failure may lead to cell death (e.g., apoptosis) or cell transformation. It is important to identify types of DNA damages and repair mechanisms involved in nanotoxicity (e.g., nucleotide excision repair, base excision repair, mismatch repair, double strand repair, direct reversal), as this understanding may suggest measures for prevention or intervention, such as the over-expression of DNA repair genes.

In the case of severe damage to DNA, cells may die by either necrosis or apoptosis. Apoptosis is a complex and highly regulated process that is invoked to eliminate irreparably damaged cells. In contrast, necrosis has long been thought of as a disorderly event (although new evidence suggests otherwise), and is considered to be a consequence of extreme physiochemical stress. Although studies have shown that exposure to certain metal oxide nanoparticles induces apoptosis [74], it is unclear which pathways are involved. There are at least four major apoptotic pathways: extrinsic apoptotic (receptor mediated pathway), intrinsic apoptotic (mitochondrial pathway), caspase-2 dependent, and caspase-independent. Again, an understanding of which pathway(s) is involved in nanoparticle induced cell death may suggest measures for prevention or mitigation.

Insofar as multiple genes have been demonstrated to be involved in responses to oxidative stress, DNA damage, and cell death (apoptosis and necrosis), a custom, pathway-specific genetic approach could serve to decipher toxicity mechanisms of nanoparticles. On the other hand, whole genome approaches may serve as a discovery tool to identify unanticipated signaling pathways. 


\subsection{Oxidative Stress and Perturbation of Intracellular Calcium Homeostasis}

The intracellular calcium concentration $\left(\left[\mathrm{Ca}^{2+}\right]_{\text {in }}\right.$ ) plays major regulatory roles in cellular metabolism, signal transduction, and gene expression. For instance, calcium can influence cell cycle by activating protein kinase $\mathrm{C}(\mathrm{PKC}), \mathrm{Ca}^{2+} /$ calmodulin-dependent protein kinases $(\mathrm{CaMK})$, and mitogen-activated protein kinase (MAPK). Accordingly, $\left[\mathrm{Ca}^{2+}\right]_{\text {in }}$ is tightly regulated, and alterations of $\left[\mathrm{Ca}^{2+}\right]_{\text {in }}$ are associated with cellular dysfunction, metabolic and energetic imbalance, disease states, and cell death. A host of environmental toxicants elevate $\left[\mathrm{Ca}^{2+}\right]_{\text {in }}$ directly or indirectly by promoting $\mathrm{Ca}^{2+}$ influx, releasing $\mathrm{Ca}^{2+}$ from intracellular stores, inhibiting $\mathrm{Ca}^{2+}$ sequestration, or blocking $\mathrm{Ca}^{2+}$ efflux from the cell [75]. A study with ultrafine particles demonstrated that calmodulin-dependent signaling pathways are crucial for cytotoxicity and cytoskeletal dysfunctions [76]. In our studies, $\mathrm{ZnO}$ caused a concentration-dependent elevation of $\left[\mathrm{Ca}^{2+}\right]_{\text {in }}$, that could be partially attenuated by the antioxidant $\mathrm{N}$-acetylcysteine (NAC), indicating an effect of oxidative stress on calcium homeostasis [43]. The inverse correlation between $\left[\mathrm{Ca}^{2+}\right]_{\text {in }}$ and cell viability suggests a role for calcium in cell death. The moderation of this increase by nifedipine suggests that a portion of this increase reflects the influx of extracellular calcium. Membrane disruption (e.g., oxidative stress-induced lipid peroxidation) may also play a role in this influx. The involvement of $\mathrm{Ca}^{2+}$ release from intracellular stores has yet to be evaluated.

In another study, the effects of $\mathrm{ZnO}$ nanoparticles on store operated calcium entry was studied in Chinese hamster ovary (CHO) cells stably transfected with a M3 muscarinic receptor. M3 receptors activate $\mathrm{G} \alpha_{\mathrm{q}}$ transducer proteins that stimulate phospholipase C $\beta$ (PLC $\beta$ ) [77]. PLC $\beta$ hydrolyzes phosphatidylinositol 4.5-bisphosphate, releasing two second messengers, diacylglycerol and inositol trisphosphate (IP3). IP3 binds to the IP3 receptor on the endoplasmic reticulum (ER) to release calcium into the cytosol. Sensors in STIM1 proteins that are components of ER membranes detect the depletion of calcium in the ER. STIM1 proteins thus activated interact with Orai channel proteins in the plasma membrane to stimulate the entry of extracellular calcium, i.e., the store operated calcium entry (SOCE) (Figure 4) [78-79]. At a non-cytotoxic concentration (10 $\mu \mathrm{g} / \mathrm{mL}), \mathrm{ZnO}$ increased resting $\left[\mathrm{Ca}^{2+}\right]_{\text {in }}$ of Chinese hamster ovary $(\mathrm{CHO})$ cells expressing $\mathrm{M} 3$ muscarinic receptors from 40 to $130 \mathrm{~nm}$ without compromising calcium homeostatic mechanisms and the $\mathrm{CHO}$ cells had no store operated calcium entry response in the presence of $10 \mu \mathrm{g} / \mathrm{ml} \mathrm{ZnO}$. Hence, $\mathrm{ZnO}$ particles had minimal effects on IP3- or thapsigargin-mediated release of intracellular calcium from the endoplasmic reticulum, but strongly inhibited store operated calcium entry. This effect was seen a decrease in $\mathrm{Ca}^{2+}$ entry upon introduction of calcium to the extracellular medium following thapsigargin-induced depletion of calcium from the endoplasmic reticulum (EC50's $\approx 2 \mu \mathrm{g} / \mathrm{ml}$ ). Thus, $\mathrm{ZnO}$ nanoparticles interfere the M3 signaling pathway (at least) via disruption of store operated calcium entry. 
Figure 4. Store-operated $\mathrm{Ca}^{2+}$ entry (SOCE). Ligand binding to certain $\mathrm{G}$ protein coupled receptors leads to activation of phospholipase $C \beta$. The IP3 thus released increases $\mathrm{Ca}^{2+}$ release from the lumen of the endoplasmic reticulum. Depletion of ER calcium leads to a Stim1 $\left(\mathrm{Ca}^{2+}\right.$ sensor $)$ - Orai $\left(\mathrm{Ca}^{2+}\right.$ channel $)$ interaction and the entry of extracellular $\mathrm{Ca}^{2+}$. $\mathrm{ZnO}$ nanoparticles inhibit this pathway by blocking the SOCE without affecting proximal receptor signaling events [67].

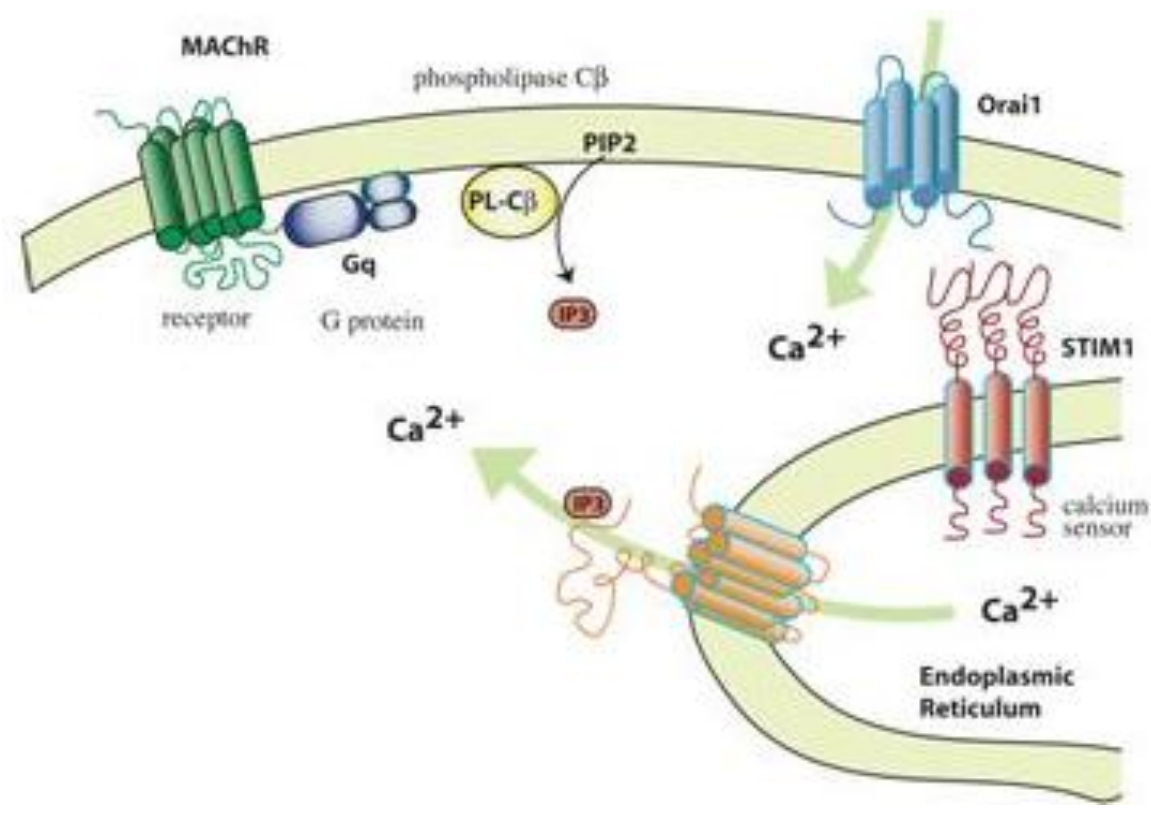

Figure 5. Relationships between $\mathrm{ZnO}$ nanoparticles, production of reactive oxygen species (OS), and intracellular $\mathrm{Ca}^{2+}$ concentrations. (modified from [43])

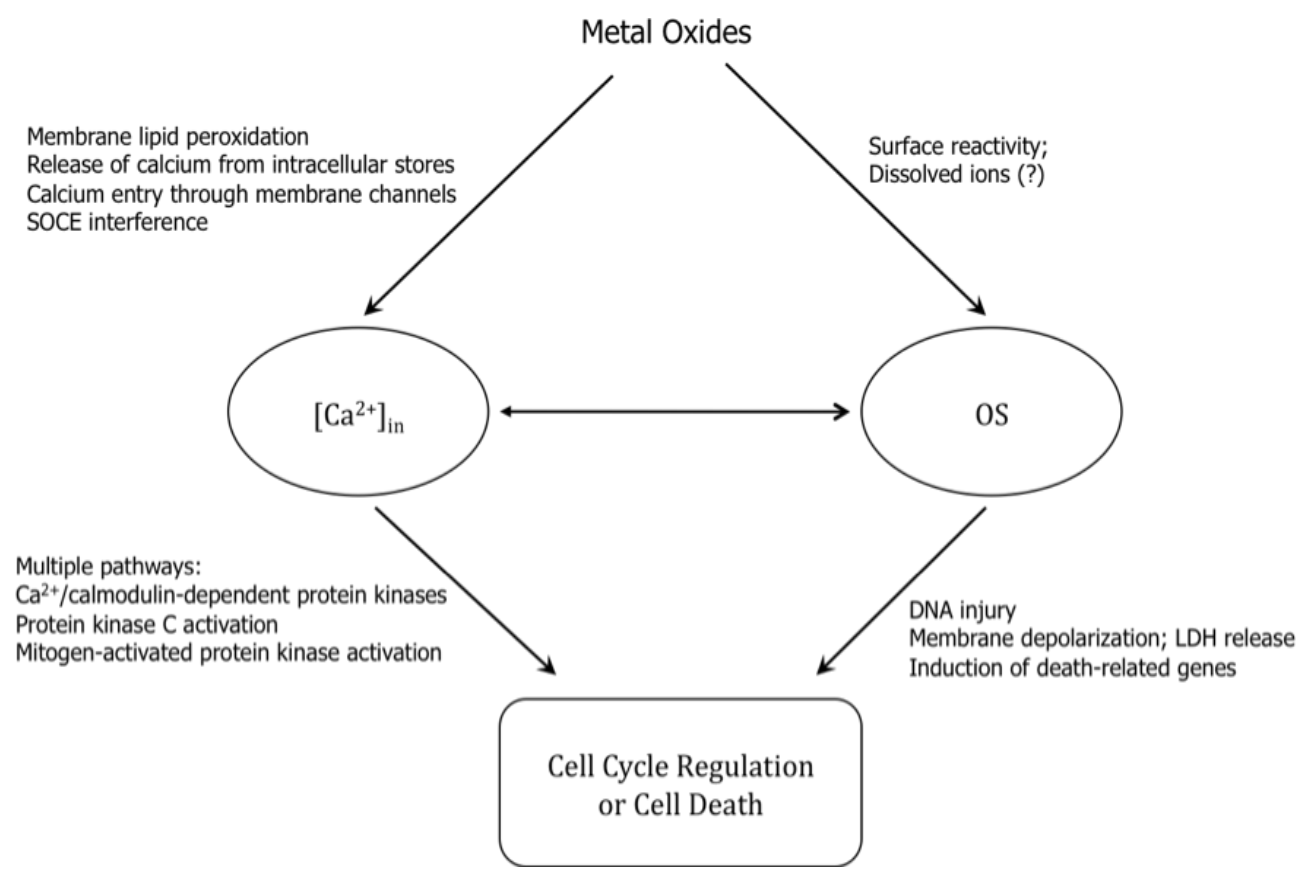

Nanoparticle-induced cell death by various means is summarized in Figure 5 [34-35,37-38,43]. The increases in intracellular content OS may have multiple sources. We postulate that the elevated 
$\mathrm{OS}$ is a consequence of $\mathrm{ZnO}$ surface reactivity and/or defects interacting with intracellular reductants in combination with the effects of dissolved metal ions that catalyze redox reactions. Synergistic interactions between intracellular $\left[\mathrm{Ca}^{2+}\right]$ and OS are a likely contributing factor. While $\left[\mathrm{Ca}^{2+}\right]_{\text {in }}$ and OS affect the activity of each other, they both induce cell death by distinct pathways. Finally, though calcium-dependent kinase activation pathways leading to cell cycle regulation or cell death have been well documented, studies in this area with transition metal oxides are lacking.

\subsection{Pro-Inflammatory Response}

Inflammation is clinically defined as the presence of redness, swelling and pain. Histologically, it is defined as the presence of edema fluid and the infiltration of tissues by phagocytic cells. Chronic inflammation can lead to diseases such as atherosclerosis, pulmonary diseases, and cancer. Oxidative stress is closely related to inflammatory response by activating the nuclear factor-kappaB (NF- $\kappa \mathrm{B})$ signaling pathway that controls the transcription of pro-inflammatory genes such as IL-1 $\beta$, IL-8, and tumor necrosis factor- $\alpha$ (TNF- $\alpha$ ) (Figure 6).

Figure 6. A model shows the simplified NF-kB signaling pathway that is activated by oxidative stress. Persistent activation leads to chronic inflammation.

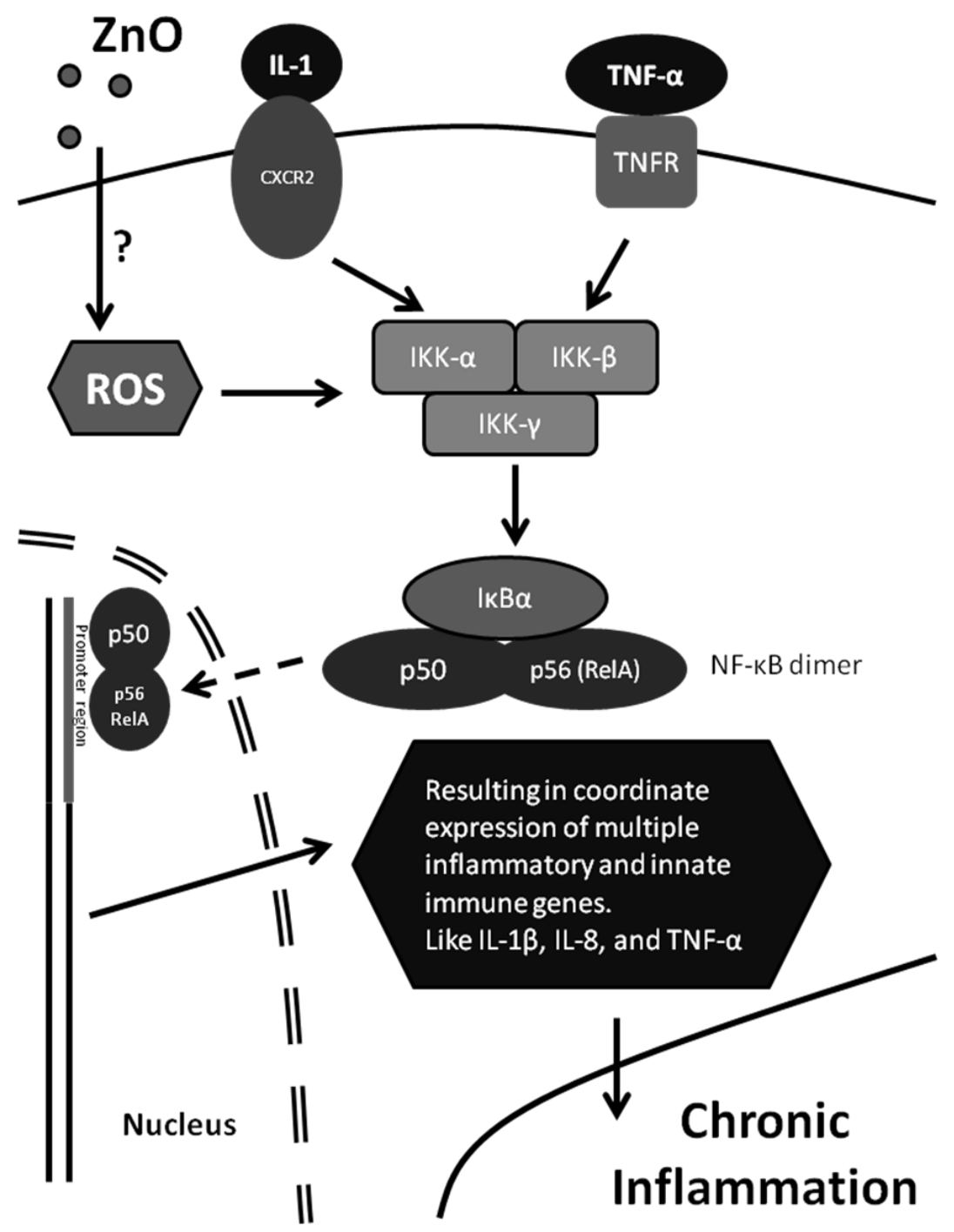


Exposure to nanoparticles has been found to result in oxidative stress-induced activation of pro-inflammatory factors such as IL-1, IL-6, IL-8, and macrophage inflammatory proteins (MIP) at both mRNA and protein levels in vitro [45,80-86]. Additional effects such as activation of IL-2, IL-4, IL-5, IL-6, IL-12, TNF- $\alpha$, increased number of polymorphonuclear leukocyte (PMN) and lymphocyte, increased $\mathrm{B}$ cell distribution, and $\mathrm{T}$ cell diminish have been observed in vivo (Table 1). These factors along with histopathological evidence can be included in the assessment of the risks associated with nanoparticle exposure.

Table 1. Pro-inflammatory responses induced by nanoparticles.

\begin{tabular}{|c|c|c|c|c|}
\hline Nanoparticle & Size (nm, diameter) & Cell type/animal & Effect & Ref. \\
\hline $\mathrm{TiO}_{2}$ & N/A & A549 cells & mRNA and protein of IL- $8 \uparrow$ & [81] \\
\hline $\mathrm{TiO}_{2}$ & $20-80$ & A549 cells & IL-8 mRNA $\uparrow$ & [80] \\
\hline $\mathrm{TiO}_{2}$ & N/A & Human neutrophils & IL-6, IL-8, MIP-1 $\alpha$, MIP-1 $\beta \uparrow$ & [86] \\
\hline $\mathrm{ZnO}$ & $24-70$ & $\begin{array}{l}\text { Lung lavage; } \\
\text { BEAS-2B cells }\end{array}$ & IL-8 mRNA $\uparrow$ in both cell types & [82] \\
\hline $\mathrm{Al}_{2} \mathrm{O}_{3}, \mathrm{Al}$ & $\begin{array}{l}\mathrm{Al}_{2} \mathrm{O}_{3}(33) \\
\mathrm{Al}(48)\end{array}$ & $\begin{array}{l}\text { U937 \& A549 } \\
\text { (co-cultured) }\end{array}$ & $\begin{array}{l}\text { Phagocytosis activity } \downarrow \text { (Al); } \\
\text { suppress immune response ( } \mathrm{Al} \& \\
\mathrm{Al}_{2} \mathrm{O}_{3} \text { ) }\end{array}$ & [45] \\
\hline Au-NPs & 50 & $\begin{array}{l}\text { Bovine retinal } \\
\text { pigment epithelial } \\
\text { cells }\end{array}$ & $\begin{array}{l}\text { Inhibit VEGF and IL- } 1 \beta \text { induced } \\
\text { proliferation and migration }\end{array}$ & [83] \\
\hline Silica & 20 & $\begin{array}{l}\text { HUVEC (human } \\
\text { umbilical vein } \\
\text { endothelial cells) }\end{array}$ & $\begin{array}{l}\text { IL-6, IL- } 8 \text {, monocyte chemotactic } \\
\text { protein-1 } \alpha(\mathrm{MIP}-1 \alpha) \uparrow\end{array}$ & [85] \\
\hline $\mathrm{Fe}$ & $20-50$ & $\begin{array}{l}\text { HL1-NB cells } \\
\text { (mouse cardiac cells) }\end{array}$ & IL-8 \& MCP-1 not changed & [84] \\
\hline $\mathrm{Fe}_{3} \mathrm{O}_{4}$ & 5.3 & ICR mouse (ठ) & $\begin{array}{l}\text { IL-1, IL-2, IL-4, IL-5, IL-6, IL-12, } \\
\text { TNF- } \alpha \text {, TGF- } \beta \text {, IgE, \& B cell } \\
\text { distribution } \uparrow . ~ T \text { cell } \\
\text { (CD4+/CD8+) diminished. }\end{array}$ & [87] \\
\hline $\begin{array}{l}\mathrm{Fe}_{3} \mathrm{O}_{4} \\
\text { (superpara } \\
\text { magnetic) }\end{array}$ & 36 & BALB/c mouse $(ð)$ & $\begin{array}{l}\text { PMN \& lymphocyte } \uparrow \text {; IL-1 } \beta \text {, } \\
\text { IL-6, TNF- } \alpha, \text { MIP- } 1 \alpha \text { mRNA } \uparrow\end{array}$ & [88] \\
\hline $\begin{array}{l}\text { SWCNT; } \\
\text { MWCNT }\end{array}$ & $\begin{array}{l}\text { SWCNT: } \\
4(W) \times 1 E 5(L) \\
\text { MWCNT: } \\
\text { 30(W) x 2E5(L) }\end{array}$ & BALB/c mouse $(q)$ & TNF- $\alpha \&$ MIP- $1 \uparrow$ & [89] \\
\hline
\end{tabular}

\section{Conclusions}

Recent studies have increased our understanding of the nanotoxicity of metal oxide particles, particularly with respect to oxidative stress-induced cascade pathways that lead to inflammatory responses. Several important challenges remain. First, inter-laboratory discrepancies contribute to uncertainties in risk assessment. Second, as new nanomaterials continue to emerge, a systematic 
approach to identifying the physicochemical properties of nanomaterials that determine toxicity is required. This is problematic using nanomaterials of industrial origin since they 1) vary in multiple physical characteristics, 2) are synthesized using different methods, and 3) vary widely in purity. Third, to attribute toxicity to a particular factor, one needs to consider the extent to which the test design is relevant to the cellular environment. It is likely that toxicity is a non-linear function of multi-variables, which highlights the necessity of developing a theoretical computing model for predictive nanotoxicity.

\section{References and Notes}

1. National Nanotechnology Coordination Center. National Nanotechnology Initiative. Available online: http://www.nano.gov/html/facts/home_facts.html. (accessed on 22 October 2006)

2. Jiang, J.; Oberdorster, G.; Elder, A.; Gelein, R.; Mercer, P.; Biswas, P. Does nanoparticle activity depend upon size and crystal phase? Nanotoxicology 2008, 2, 33-42.

3. Fubini, B.; Hubbard, A. Reactive oxygen species (ROS) and reactive nitrogen species (RNS) generation by silica in inflammation and fibrosis. Free Radic Biol. Med. 2003, 34, 1507-1516.

4. Mossman, B.T.; Churg, A. Mechanisms in the pathogenesis of asbestosis and silicosis. Am. J. Respir. Crit. Care Med. 1998, 157, 1666-1680.

5. Schins, R.P. Mechanisms of genotoxicity of particles and fibers. Inhal. Toxicol. 2002, 14, 57-78.

6. Knaapen, A.M.; Borm, P.J.; Albrecht, C.; Schins, R.P. Inhaled particles and lung cancer. Part A: Mechanisms. Int. J. Cancer. 2004, 109, 799-809.

7. van Maanen, J.M.; Borm, P.J.; Knaapen, A.; van Herwijnen, M.; Schilderman, P.A.; Smith, K.R.; Aust, A.E.; Tomatis, M.; Fubini, B. In vitro effects of coal fly ashes: hydroxyl radical generation, iron release, and DNA damage and toxicity in rat lung epithelial cells. Inhalation Toxicol. 1999, $11,1123-1141$.

8. Driscoll, K.E.; Deyo, L.C.; Carter, J.M.; Howard, B.W.; Hassenbein, D.G.; Bertram, T.A. Effects of particle exposure and particle-elicited inflammatory cells on mutation in rat alveolar epithelial cells. Carcinogenesis 1997, 18, 423-430.

9. Zhong, B.Z.; Whong, W.Z.; Ong, T.M. Detection of mineral-dust-induced DNA damage in two mammalian cell lines using the alkaline single cell gel/comet assay. Mutat. Res. 1997, 393, 181-187.

10. Leanderson, P.; Tagesson, C. Hydrogen peroxide release and hydroxyl radical formation in mixtures containing mineral fibres and human neutrophils. Br. J. Ind. Med. 1992, 49, 745-759.

11. Borm, P.J.; Schins, R.P.; Albrecht, C. Inhaled particles and lung cancer, part B: Paradigms and risk assessment. Int. J. Cancer 2004, 110, 3-14.

12. Xia, T.; Kovochich, M.; Brant, J.; Hotze, M.; Sempf, J.; Oberley, T.; Sioutas, C.; Yeh, J.I.; Wiesner, M.R.; Nel, A.E. Comparison of the abilities of ambient and manufactured nanoparticles to induce cellular toxicity according to an oxidative stress paradigm. Nano Lett. 2006, 6, 1794-1807.

13. Noronha, F.B.; Schmal, M.; Nicot, C.; Moraweck, B.; Frety, R. Characterization of graphite-supported palladium-cobalt catalysts by temperature-programmed reduction and magnetic measurements. J. Catal. 1997, 168, 42-50. 
14. Roy, S.; Das, D.; Chakravorty, D.; Agrawal, D.C. Magnetic-properties of glass-metal nanocomposites prepared by the sol-gel route and hot-pressing. J. Appl. Phys. 1993, 74, 4746-4749.

15. Prinz, G.A. Magnetoelectronics. Science 1999, 283, 330-330.

16. Vassiliou, J.K.; Mehrotra, V.; Russell, M.W.; Giannelis, E.P.; Mcmichael, R.D.; Shull, R.D.; Ziolo, R.F. Magnetic and optical-properties of gamma- $\mathrm{Fe}_{2} \mathrm{O}_{3}$ nanocrystals. J. Appl. Phys. 1993, 73, 5109-5116.

17. Airapetyan, S.S.; Balayan, G.G.; Khachatryan, A.G. Synthesis and some characteristics of magnetic matrices for fixation of biologically active substances. Russ. J. Appl. Chem. 2001, 74, 519-521.

18. Kobe, S.; Drazic, G.; McGuiness, P.J.; Strazisar, J. The influence of the magnetic field on the crystallisation form of calcium carbonate and the testing of a magnetic water-treatment device. J. Magn. Mag. Mater. 2001, 236, 71-76.

19. Gruttner, C.; Teller, J. Preparation and characterization of magnetic nanoparticles for in-vivo applications. In Scientific and Clinical Applications of Magnetic Carriers; Hafeli, U., Schutt, W., Teller, J., Zborowski, M., Eds; Plenum Publishing Corporation: New York, NY, USA, 1997; p. 53.

20. Howard, M.A., III; Dacey, R.G.; Grady, M.S.; Ritter, R.C.; Gillies, G.T. Magnetically guided stereotaxis. In Advanced Neurosurgical Navigation; Alexander, E., III, Maciunas, R.J., Eds; Thieme Medical Publishers: New York, NY, USA, 1999; pp. 549-563.

21. Howard, M.A., III; Grady, M.S.; Ritter, R.C.; Gillies, G.T.; Broaddus, W.C.; Dacey, R.G. Magnetic neurosurgery. In Stereotactic and Functional Neurosurgery; Lozano, Gildenberg \& Tasker, Ed; Karger Pulbisher: Basel, Switzerland, 1996; pp. 102-107.

22. Grady, M.S.; Howard, M.A.; Dacey, R.G.; Blume, W.; Lawson, M.; Werp, P.; Ritter, R.C. Experimental study of the magnetic stereotaxis system for catheter manipulation within the brain. J. Neurosurg. 2000, 93, 282-288.

23. Wellman, B.J.; Howard, M.A., III; Dacey, R.G.; Grady, M.S.; Ritter, R.C.; Gillies, G.T. Magnetically guided interventional medicine. In Proceedings of the Biomedical Optics. SurgicalAssist Systems, San Jose, CA, USA, January 25-28, 1998; pp. 15-25.

24. Zhu, B.L.; Xie, C.S.; Zeng, D.W.; Song, W.L.; Wang, A.H. Investigation of gas sensitivity of Sb-doped ZnO nanoparticles. Mater. Chem. Phys. 2005, 89, 148-153.

25. Ramakrishna, G.G. Effect of particle size on the reactivityof quantum size $\mathrm{ZnO}$ nanoparticles and charge-transfer dynamics with adsorbed catechols. Langmuir 2003, 19, 3006-3012.

26. Huang, G.G.; Wang, C.T.; Tang, H.T.; Huang, Y.S.; Yang, J. ZnO nanoparticle-modified infrared internal relfection elements for selective detection of volatile organic compounds. Anal. Chem. 2006, 78, 2397-2404.

27. Ding, Y.; Wang, Z.L. Structure analysis of nanowires and nanobelts by transmission electron microscopy. J. Phys. Chem. 2004, 108, 12280-12291.

28. Comini, E.; Faglia, G.; Sberveglieri, G.; Pan, Z.; Wang, Z.L. Stable and highly sensitive gas sensors based on semiconducting oxide nanobelts. Appl. Phys. Lett. 2002, 81, 1869-1871.

29. Bai, X.D.; Gao, P.X.; Wang, Z.L.; Wang, E.G. Dual-mode mechanical resonance of individual $\mathrm{ZnO}$ nanobelts. Appl. Phys. Lett. 2003, 28, 4806-4808.

30. Bae, S.Y.; Seo, H.W. Vertically aligned sulfur-doped $\mathrm{ZnO}$ nanowires synthesized via chemical vapor deposition. J. Phys. Chem. 2004, 108, 5206-5210. 
31. Kumar, S.A.; Chen, S.M. Nanostructured Zinc Oxide Particles in Chemically Modified Electrodes for Biosensor Applications. Anal. Lett. 2008, 41, 141-158.

32. Xia, T.; Kovochich, M.; Liong, M.; Madler, L.; Gilbert, B.; Shi, H.; Yeh, J.I.; Zink, J.I.; Nel, A.E. Comparison of the mechanism of toxicity of zinc oxide and cerium oxide nanoparticles based on dissolution and oxidative stress properties. ACS Nano 2008, 2, 2121-2134.

33. Lai, J.C.; Lai, M.B.; Jandhyam, S.; Dukhande, V.V.; Bhushan, A.; Daniels, C.K.; Leung, S.W. Exposure to titanium dioxide and other metallic oxide nanoparticles induces cytotoxicity on human neural cells and fibroblasts. Int. J. Nanomed. 2008, 3, 533-545.

34. Lin, W.; Stayton, I.; Huang, Y.W.; Zhou, X.D.; Ma, Y. Cytotoxicity and cell membrane depolarization induced by aluminum oxide nanoparticles in human lung epithelial cells A549. Toxico. Environ. Chem. 2008, 90, 983-996.

35. Lin, W.; Xu, Y.; Huang, C.C.; Ma, Y.; Shannon, K.B.; Chen, D.R.; Huang, Y.W. Toxicity of nano- and micro-sized $\mathrm{ZnO}$ particles in human lung epithelial cells. J. Nanopart. Res. 2009, 11, 25-39.

36. Kang, S.G.; Brown, A.L.; Chung, J.H. Oxygen tension regulates the stability of insulin receptor substrate-1 (IRS-1) through caspase-mediated cleavage. J. Biol. Chem. 2007, 282, 6090-6097.

37. Lin, W.; Huang, Y.W.; Zhou, X.D.; Ma, Y. In vitro toxicity of silica nanoparticles in human lung cancer cells. Toxico. Appl. Pharmacol. 2006, 217, 252-259.

38. Lin, W.; Huang, Y.W.; Zhou, X.D.; Ma, Y. Toxicity of cerium oxide nanoparticles in human lung cancer cells. Int. J. Toxicol. 2006, 25, 451-457.

39. Fahmy, B.; Cormier, S.A. Copper oxide nanoparticles induce oxidative stress and cytotoxicity in airway epithelial cells. Toxicol. in vitro 2009, 23, 1365-1371.

40. Vamanu, C.I.; Cimpan, M.R.; Hol, P.J.; Sornes, S.; Lie, S.A.; Gjerdet, N.R. Induction of cell death by TiO2 nanoparticles: Studies on a human monoblastoid cell line. Toxicol. in vitro 2008, 22, 1689-1696.

41. Komatsu, T.; Tabata, M.; Kubo-Irie, M.; Shimizu, T.; Suzuki, K.; Nihei, Y.; Takeda, K. The effects of nanoparticles on mouse testis Leydig cells in vitro. Toxicol. in vitro 2008, 22, 1825-1831.

42. Ivankovic, S.; Music, S.; Gotic, M.; Ljubesic, N. Cytotoxicity of nanosize $\mathrm{V}_{2} \mathrm{O}_{5}$ particles to selected fibroblast and tumor cells. Toxicol. in vitro 2006, 20, 286-294.

43. Huang, C.C.; Aronstam, R.S.; Chen, D.R.; Huang, Y.W. Oxidative stress, calcium homeostasis, and altered gene expression in human lung epithelial cells exposed to $\mathrm{ZnO}$ nanoparticles. Toxicol. in vitro 2010, 24, 45-55.

44. Sarkar, S.; Sharma, C.; Yog, R.; Periakaruppan, A.; Jejelowo, O.; Thomas, R.; Barrera, E.V.; Rice-Ficht, A.C.; Wilson, B.L.; Ramesh, G.T. Analysis of stress responsive genes induced by single-walled carbon nanotubes in BJ Foreskin cells. J. Nanosci. Nanotechnol. 2007, 7, 584-592.

45. Braydich-Stolle, L.K.; Speshock, J.L.; Castle, A.; Smith, M.; Murdock, R.C.; Hussain, S.M. Nanosized aluminum altered immune function. ACS Nano 2010, 4, 3661-3670.

46. Donaldson, K.; Borm, P.J.; Castranova, V.; Gulumian, M. The limits of testing particle-mediated oxidative stress in vitro in predicting diverse pathologies; relevance for testing of nanoparticles. Part. Fibre. Toxicol. 2009, 6, 13. 
47. Limbach, L.K.; Li, Y.; Grass, R.N.; Brunner, T.J.; Hintermann, M.A.; Muller, M.; Gunther, D.; Stark, W.J. Oxide nanoparticle uptake in human lung fibroblasts: Effects of particle size, agglomeration, and diffusion at low concentrations. Environ. Sci. Technol. 2005, 39, 9370-9376.

48. Nakase, I.; Niwa, M.; Takeuchi, T.; Sonomura, K.; Kawabata, N.; Koike, Y.; Takehashi, M.; Tanaka, S.; Ueda, K.; Simpson, J.C.; Jones, A.T.; Sugiura, Y.; Futaki, S. Cellular uptake of arginine-rich peptides: roles for macropinocytosis and actin rearrangement. Mol. Ther. 2004, 10, 1011-1022.

49. Wadia, J.S.; Dowdy, S.F. Transmembrane delivery of protein and peptide drugs by TAT-mediated transduction in the treatment of cancer. Adv. Drug Deliv. Rev. 2005, 57, 579-596.

50. Tyagi, M.; Rusnati, M.; Presta, M.; Giacca, M. Internalization of HIV-1 tat requires cell surface heparan sulfate proteoglycans. J. Biol. Chem. 2001, 276, 3254-3261.

51. Bahattacharjee, S.; Haan, L.H.J.; Evers, N.M.; Jiang, X.; Marcelis, A.T.M.; Zuihof, H.; Rietjens, I.M.C.M.; Alink, G.M. Role of surface charge and oxidative stress in cytotoxicity of organic monolayer-coated silicon nanoparticles towards macrophage NR8383 cells. Part. Fibre. Toxicol. 2010, 7, 25.

52. Kam, N.W.; Dai, H. Carbon nanotubes as intracellular protein transporters: Generality and biological functionality. J. Am. Chem. Soc. 2005, 127, 6021-6026.

53. Xu, Y.; Liu, B.R.; Lee, H.J.; Shannon, K.B.; Winiarz, J.G.; Wang, T.C.; Chiang, H.J.; Huang, Y.W. Nona-arginine facilitates delivery of quantum dots into cells via multiple pathways. J. Biomed. Biotechnol. 2010, in press.

54. Liu, B.R.; Li, J.F.; Lu, S.W.; Lee, H.J.; Shannon, K.B.; Huang, Y.W.; Aronstam, R.S. Cellular internalization of quantum dots noncovalently conjugated with arginine-rich intracellular delivery peptides. J. Nanosci. Nanotechnol. 2010, 10, 6534-6543.

55. Ruan, G.; Agrawal, A.; Marcus, A.I.; Nie, S. Imaging and tracking of Tat peptide-conjugated quantum dots in living Cells: New Insights into nanoparticle uptake, intracellular transport, and vesicle shedding. J. Am. Chem. Soc. 2007, 129, 14759-14766.

56. Krpetic, Z.; Porta, F.; Caneva, E.; Dal Santo, V.; Scari, G. Phagocytosis of biocompatible gold nanoparticles. Langmuir 2010, 26, 14799-14805.

57. Jin, C.Y.; Zhu, B.S.; Wang, X.F.; Lu, Q.H. Cytotoxicity of titanium dioxide nanoparticles in mouse fibroblast cells. Chem. Res. Toxicol. 2008, 21, 1871-1877.

58. Karlsson, H.L.; Cronholm, P.; Gustafsson, J.; Moller, L. Copper oxide nanoparticles are highly toxic: A comparison between metal oxide nanoparticles and carbon nanotubes. Chem. Res. Toxicol. 2008, 21, 1726-1732.

59. Hu, X.; Cook, S.; Wang, P.; Hwang, H.M. In vitro evaluation of cytotoxicity of engineered metal oxide nanoparticles. Sci. Total. Environ. 2009, 407, 3070-3072.

60. Kasemets, K.; Ivask, A.; Dubourguier, H.C.; Kahru, A. Toxicity of nanoparticles of $\mathrm{ZnO}, \mathrm{CuO}$ and $\mathrm{TiO} 2$ to yeast Saccharomyces cerevisiae. Toxicol. in vitro 2009, 23, 1116-1122.

61. Limbach, L.K.; Wick, P.; Manser, P.; Grass, R.N.; Stark, W.J. Exposure of engineered nanoparticles to human lung epithelial cells: Influence of chemical composition and catalytic activity on oxidative stress. Eviron. Sci. Technol. 2007, 41, 4158-4163. 
62. Horie, M.; Nishio, K.; Fujita, K.; Endoh, S.; Miyauchi, A.; Saito, Y.; Iwahashi, H.; Yamamoto, K.; Murayama, H.; Nakano, H.; Nanashima, N.; Niki, E.; Yoshida, Y. Protein adsorption of ultrafine metal oxide and its influence on cytotoxicity toward cultured cells. Chem. Res. Toxicol. 2009, 22, 543-553.

63. George, S.; Pokhrel, S.; Xia, T.; Gilbert, B.; Ji, Z.; Schowalter, M.; Rosenauer, A.; Damoiseaux, R.; Bradley, K.A.; Madler, L.; Nel, A.E. Use of a rapid cytotoxicity screening approach to engineer a safer zinc oxide nanoparticle through iron doping. ACS Nano 2010, 4, 15-29.

64. Chan, K.; Kan, Y.W. Nrf2 is essential for protection against acute pulmonary injury in mice. Proc. Natl. Acad. Sci. USA 1999, 96, 12731-12736.

65. Hayes, J.D.; Chanas, S.A.; Henderson, C.J.; McMahon, M.; Sun, C.; Moffat, G.J.; Wolf, C.R.; Yamamoto, M. The Nrf2 transcription factor contributes both to the basal expression of glutathione S-transferases in mouse liver and to their induction by the chemopreventive synthetic antioxidants, butylated hydroxyanisole and ethoxyquin. Biochem. Soc. Trans. 2000, 28, 33-41.

66. Itoh, K.; Chiba, T.; Takahashi, S.; Ishii, T.; Igarashi, K.; Katoh, Y.; Oyake, T.; Hayashi, N.; Satoh, K.; Hatayama, I.; Yamamoto, M.; Nabeshima, Y. An Nrf2/small Maf heterodimer mediates the induction of phase II detoxifying enzyme genes through antioxidant response elements. Biochem. Biophys. Res. Commun. 1997, 236, 313-322.

67. Eom, H.J.; Choi, J. Oxidative stress of $\mathrm{CeO} 2$ nanoparticles via p38-Nrf-2 signaling pathway in human bronchial epithelial cell, Beas-2B. Toxicol. Lett. 2009, 187, 77-83.

68. Aoki, Y.; Sato, H.; Nishimura, N.; Takahashi, S.; Itoh, K.; Yamamoto, M. Accelerated DNA adduct formation in the lung of the Nrf2 knockout mouse exposed to diesel exhaust. Toxicol. Appl. Pharmacol. 2001, 173, 154-160.

69. Simmons, T.W.; Jamall, I.S. Relative importance of intracellular glutathione peroxidase and catalase in vivo for prevention of peroxidation to the heart. Cardiovasc. Res. 1989, 23, 774-779.

70. Wang, S.; Kotamraju, S.; Konorev, E.; Kalivendi, S.; Joseph, J.; Kalyanaraman, B. Activation of nuclear factor-kappaB during doxorubicin-induced apoptosis in endothelial cells and myocytes is pro-apoptotic: The role of hydrogen peroxide. Biochem. J. 2002, 367, 729-740.

71. Bhattacharya, K.; Davoren, M.; Boertz, J.; Schins, R.P.; Hoffmann, E.; Dopp, E. Titanium dioxide nanoparticles induce oxidative stress and DNA-adduct formation but not DNA-breakage in human lung cells. Part. Fibre. Toxicol. 2009, 6, 17.

72. Falck, G.C.; Lindberg, H.K.; Suhonen, S.; Vippola, M.; Vanhala, E.; Catalan, J.; Savolainen, K.; Norppa, H. Genotoxic effects of nanosized and fine $\mathrm{TiO}_{2}$. Hum. Exp. Toxicol. 2009, 28, 339-352.

73. Rahman, Q.; Lohani, M.; Dopp, E.; Pemsel, H.; Jonas, L.; Weiss, D.G.; Schiffmann, D. Evidence that ultrafine titanium dioxide induces micronuclei and apoptosis in Syrian hamster embryo fibroblasts. Environ. Health Perspect 2002, 110, 797-800.

74. Jeng, H.A.; Swanson, J. Toxicity of metal oxide nanoparticles in mammalian cells. J. Environ. Sci. Health, Part A: Toxic/ Hazardous Subst. Environ. Eng. 2006, 41, 2699-2711.

75. Stone, V.; Tuinman, M.; Vamvakopoulos, J.E.; Shaw, J.; Brown, D.; Petterson, S.; Faux, S.P.; Borm, P.; MacNee, W.; Michaelangeli, F.; Donaldson, K. Increased calcium influx in a monocytic cell line on exposure to ultrafine carbon black. Eur. Respir. J. 2000, 15, 297-303.

76. Moller, W.; Brown, D.M.; Kreyling, W.G.; Stone, V. Ultrafine particles cause cytoskeletal dysfunctions in macrophages: Role of intracellular calcium. Part. Fibre. Toxicol. 2005, 2, 7. 
77. Aronstam, R.S.; Patil, P. Receptors on autonomic neurons and neuroeffector cells: Muscarinic receptors. In Encyclopedia of Neuroscience. Adelman, G., Smith, B., Eds.; Elsevier Press: Amstersam, The Netherlands, 2008.

78. Smyth, J.T.; Dehaven, W.I.; Bird, G.S.; Putney, J.W., Jr. Ca2+-store-dependent and -independent reversal of Stim1 localization and function. J. Cell Sci. 2008, 121, 762-772.

79. Putney, J.W., Jr. Recent breakthroughs in the molecular mechanism of capacitative calcium entry (with thoughts on how we got here). Cell Calcium 2007, 42, 103-110.

80. Singh, S.; Shi, T.; Duffin, R.; Albrecht, C.; van Berlo, D.; Hohr, D.; Fubini, B.; Martra, G.; Fenoglio, I.; Borm, P.J.; Schins, R.P. Endocytosis, oxidative stress and IL-8 expression in human lung epithelial cells upon treatment with fine and ultrafine TiO2: Role of the specific surface area and of surface methylation of the particles. Toxicol. Appl. Pharmacol. 2007, 222, 141-151.

81. Monteiller, C.; Tran, L.; MacNee, W.; Faux, S.; Jones, A.; Miller, B.; Donaldson, K. The pro-inflammatory effects of low-toxicity low-solubility particles, nanoparticles and fine particles, on epithelial cells in vitro: The role of surface area. Occup. Environ. Med. 2007, 64, 609-615.

82. Wu, W.; Samet, J.M.; Peden, D.B.; Bromberg, P.A. Phosphorylation of p65 is required for zinc oxide nanoparticle-induced interleukin 8 expression in human bronchial epithelial cells. Environ. Health Perspect 2010, 118, 982-987.

83. Karthikeyan, B.; Kalishwaralal, K.; Sheikpranbabu, S.; Deepak, V.; Haribalaganesh, R.; Gurunathan, S. Gold nanoparticles downregulate VEGF-and IL-1beta-induced cell proliferation through Src kinase in retinal pigment epithelial cells. Exp. Eye Res. 2010, 91, 769-778.

84. Kahn, E.; Baarine, M.; Pelloux, S.; Riedinger, J.M.; Frouin, F.; Tourneur, Y.; Lizard, G. Iron nanoparticles increase 7-ketocholesterol-induced cell death, inflammation, and oxidation on murine cardiac HL1-NB cells. Int. J. Nanomed. 2010, 5, 185-195.

85. Liu, X.; Sun, J. Endothelial cells dysfunction induced by silica nanoparticles through oxidative stress via JNK/P53 and NF-kappaB pathways. Biomaterials. 2010, 31, 8198-8209.

86. Goncalves, D.M.; Chiasson, S.; Girard, D. Activation of human neutrophils by titanium dioxide (TiO2) nanoparticles. Toxicol. in vitro 2010, 24, 1002-1008.

87. Park, E.J.; Kim, H.; Kim, Y.; Yi, J.; Choi, K.; Park, K. Inflammatory responses may be induced by a single intratracheal instillation of iron nanoparticles in mice. Toxicology 2010, 275, 65-71.

88. Cho, W.S.; Cho, M.; Kim, S.R.; Choi, M.; Lee, J.Y.; Han, B.S.; Park, S.N.; Yu, M.K.; Jon, S.; Jeong, J. Pulmonary toxicity and kinetic study of Cy5.5-conjugated superparamagnetic iron oxide nanoparticles by optical imaging. Toxicol. Appl. Pharmacol. 2009, 239, 106-115.

89. Nygaard, U.C.; Hansen, J.S.; Samuelsen, M.; Alberg, T.; Marioara, C.D.; Lovik, M. Single-walled and multi-walled carbon nanotubes promote allergic immune responses in mice. Toxicol. Sci. 2009, 109, 113-123.

(C) 2010 by the authors; licensee MDPI, Basel, Switzerland. This article is an open access article distributed under the terms and conditions of the Creative Commons Attribution license (http://creativecommons.org/licenses/by/3.0/). 